\title{
Pengembangan Lembar Kerja Siswa (LKS) Model Saintifik untuk Melatih Kemampuan Berpikir Kreatif Siswa Sekolah Dasar
}

\author{
Budiman \\ Program Studi Pendidikan Jasmani Kesehatan dan Rekreasi, STKIP Yapis Dompu \\ E-mail: $\underline{\text { budimanmsaid@gmail.com }}$
}

Article History: Received: 2021-05-12 || Revised: 2021-07-17 || Published: 2021-08-15

Sejarah Artikel : Diterima: 2021-05-12 || Direvisi: 2021-07-17 || Dipublikasi: 2021-08-15

\begin{abstract}
This type of research is the development of research(developmentalreseach) which refers to the model 4$\mathrm{D}$ (four-D) design uses a technique penelitrtian one shot case study. Data collection techniques in this study were observation and questionnaires (questionnaires). The data analysis technique used in this research is descriptive analysis technique using descriptive statistics including validation analysis of learning devices, analysis of the practicality of learning tools, analysis of the effectiveness of learning devices. Based on the results of the study, it was obtained that the validation analysis of learning tools consisting of an average student worksheet validation 3.3 validation of the creative thinking ability test 3.2 validation of the student response questionnaire instrument 3.5 and the validation of the student activity observation sheet instrument 3.0 in order to obtain an average the final average of the four devices is 3.3 and is included in the category of fit for use. In the analysis of the practicality of learning tools for five respondents through observations of student activities, the reliability obtained was $98 \%$ in the good category. The analysis of the effectiveness of the learning device consisted of analyzing a student response questionnaire covering seven components with a value range of $81-100 \%$ with very strong criteria on six components and one component with a value range of $61-80 \%$ strong criteria. The analysis of the creative thinking ability test was carried out on five respondents.
\end{abstract}

Keywords: Student Worksheets, Scientific Model, Creative Thinking.

\begin{abstract}
Abstrak
Penelitian ini bertujuan untuk menghasilkan lembar kerja siswa model saintifik yang layak untuk meningkatkan kemampuan berpikir kreatif siswa sekolah dasar. Jenis penelitian ini merupakan penelitian pengembangan (developmental reseach) yang mengacu pada model 4-D (four-D) desain penelitian ini menggunakan teknik one shot case study. Teknik pengumpulan data dalam penelitian ini adalah observasi dan kuesioner (angket). Adapun teknik analisis data yang digunakan dalam penelitian ini adalah teknik analisis deskriptif dengan menggunakan statistik deskriptif meliputi analisis validasi perangkat pembelajaran, analisis kepraktisan perangkat pembelajaran, analisis keefektifan perangkat pembelajaran. Berdasarkan hasil penelitian diperoleh analisis validasi perangkat pembelajaran yang terdiri rata-rata validasi lembar kerja siswa 3,3 validasi tes kemampuan berpikir kreatif 3,2 validasi instrumen angket respon siswa 3,5 dan validasi instrumen lembar pengamatan aktivitas siswa 3,0 sehingga diperoleh rata-rata akhir dari keempat perangkat tersebut adalah 3,3 dan termasuk pada kategori layak digunakan. pada analisis kepraktisan perangkat pembelajaran terhadap lima responden melalui pengamatan aktivitas siswa diperoleh reliabilitas $98 \%$ dengan kategori baik. Analisis keefektifan perangkat pembelajran terdiri dari analisi angket repon siswa mencakup tujuh komponen dengan rentang nilai 81-100\% dengan kriteria sangat kuat pada enam komponen dan satu komponen dengan rentang nilai 61-80\% kriteria kuat. Analisis tes kemampuan berpikir kreatif ini dilakukan terhadap lima responden.
\end{abstract}

Kata kunci: Lembar Kerja Siswa, Model Saintifik, Berpikir Kreatif.

\section{PENDAHULUAN}

Pendidikan merupakan usaha sadar dan terencana untuk mewujudkan suasana belajar dan proses pembelajaran agar peserta didik secara aktif mengembangkan potensi dirinya untuk memiliki kekuatan spiritual keagamaan, pengendalian diri, kepribadian, kecerdasan, akhlak mulia, serta keterampilan yang diperlukan dirinya, masyarakat, bangsa dan Negara. (UU No. 20 Tahun 2003). Melalui proses pendidikan memberi kesempatan kepada peserta didik untuk mengembangkan 
potensi dirinya menjadi kemampuan berpikir rasional dan kecemerlangan akademik dengan memberikan makna terhadap apa yang dilihat, didengar, dibaca, dipelajari dari warisan budaya berdasarkan makna yang ditentukan oleh lensa budayanya dan sesuai dengan tingkat kematangan psikologis serta kematangan fisik peserta didik.

Peserta didik adalah pewaris budaya bangsa yang kreatif. Menurut pandangan filosofi ini, prestasi bangsa di berbagai bidang kehidupan di masa lampau adalah sesuatu yang harus termuat dalam isi kurikulum untuk dipelajari peserta didik. (Permendikbud No. 57 Tahun 2014 tentang Kurikulum 2013 sekolah dasar). Tugas mempersiapkan generasi muda bangsa menjadi tugas utama suatu kurikulum. Untuk mempersiapkan kehidupan masa kini dan masa depan peserta didik, Kurikulum 2013 mengembangkan pengalaman belajar dan kesempatan luas bagi peserta didik untuk menguasai kompetensi yang diperlukan bagi kehidupan di masa kini dan masa depan, dengan demikian tujuan kurikulum 2013 yaitu untuk mempersiapkan manusia Indonesia agar memiliki kemampuan hidup sebagai pribadi dan warga negara yang beriman, produktif, kreatif, inovatif, dan afektif serta mampu berkontribusi pada kehidupan bermasyarakat, berbangsa, bernegara, dan peradaban dunia. Karena seiring dengan tingkat kompleksitas dalam segala aspek kehidupan modern yang sangat tinggi pada era globalisasi kemampuan berpikir kritis, kreatif dan produktif di kalangan peserta didik sangat mutlak diperlukan.

Kurikulum 2013 menggunakan pembelajaran tematik terpadu kecuali Pendidikan Agama dan Budi Pekerti. Penguatan pembelajaran aktif-mencari yaitu siswa aktif mencari. Dengan memberi waktu yang cukup leluasa dan menerapkan pembelajaran model saintifik mampu mengembangkan berbagai sikap, pengetahuan, dan keterampilan yang dimiliki peserta didik. Sikap diperoleh melalui aktivitas menerima, menjalankan, menghargai, menghayati, dan mengamalkan. Pengetahuan diperoleh melalui aktivitas mengingat, memahami, menerapkan, menganalisis, mengevaluasi, mencipta. Keterampilan diperoleh melalui aktivitas mengamati, menanya, mencoba, menalar, menyaji, dan mencipta. (Permendikbud No. 65 Tahun 2013), Penerapan model saintifik dalam proses pembelajaran mampu mengasah keterampilan siswa dan membantu siswa lebih kreatif, aktif dan memecahkan masalah. Istilah kreatif memiliki makna bahwa pembelajaran merupakan sebuah proses mengembangkan kreativitas siswa, karena pada dasarnya individu memiliki imajinasi dan rasa ingin tahu. Menurut Rawlinson, (1989:11) setiap manusia memiliki kapasitas untuk menggunakan pikiran dan imajinasi mereka secara konstruktif menghasilkan sesuatu yang baru. Susanto, (2013:109) mengemukakan kreativitas adalah kemampuan untuk mengungkapkan hubungan-hubungan baru, melihat sesuatu dari sudut pandang baru dan membentuk kombinasi baru dari dua konsep atau lebih yang dikuasai sebelumnya, berpikir kreatif dapat dimaknai dengan berpikir yang dapat menghubungkan atau melihat sesuatu dari sudut pandang baru.

Senada dengan hal tersebut pada lembaga pendidikan Sekolah Dasar No.7 Dompu berusaha keras untuk menciptakan pembelajaran yang aktif dan kreatif. Namun dalam prosesnya tentu mengalami kendala-kendala. Salah satu kendala yang dihadapi oleh guru kelas III/a adalah pemanfaatan sumber daya yang ada. Seperti bahan ajar yang digunakan masih terbatas pada penggunaan buku siswa belum disertai dengan bahan ajar pendamping seperti lembar kerja siswa dan penggunaan alat peraga. Karena berdasarkan hasil wawancara yang dilakukan pada tanggal 3 Maret 2020 pukul 09.30 wita dengan salah satu guru kelas tiga-a berinisial ' $R$ ', beliau menyebutkan bahwa lembar kerja siswa yang digunakan selama ini adalah produk yang diperjual belikan. Beliau memahami banyak kekurangan dan dampak dari penggunaan lembar kerja siswa produk terbitan perusahaan ini atau yang diperjual belikan. Karena terkadang materi yang disajikan tidak sesuai dengan silabus dan RPP, penggunaan kata yang sulit dipahami maknanya oleh siswa sekolah dasar. Lebih lanjut beliau menyatakan kurang kreatif dalam membuat lembar kerja siswa dengan alasan belum memahami komponen-komponen yang harus ada di dalam lembar kerja siswa apalagi sekarang menggunakan model saintifik. Selain itu, beliau juga memaparkan ketidakmampuannya dalam pengoperasian teknologi informasi atau lebih khususnya computer atau laptop. Hal ini menyebabkan guru menjadi tidak inovatif, kreatif dan tidak menghiraukan kompetensi yang akan diperoleh siswa.

Mbasi (2016:73) menyatakan LKS adalah panduan siswa yang digunakan untuk melakukan kegiatan penyelidikan atau pemecahan masalah. LKS disusun berdasarkan atas buku pembelajaran yang mengacu pada kurikulum. LKS yang baik adalah lembar kerja yang dapat membantu siswa 
belajar, dirancang secara menarik, baik dari segi bentuk maupun isi dan berdampak pada pengembangan kemampaun berpikir, berbuat dan bersikap. Selain itu LKS harus dapat membantu siswa memecahkan masalah yang sederhana maupun rumit, tidak menimbulkan persepsi yang salah, serta dapat dipertanggung jawabkan kebenarannya.

Dengan tuntutan kurikulum 2013 yang mengharuskan siswa lebih aktif dibandingkan dengan guru. Jadi peneliti tertarik untuk mengembangkan lembar kerja siswa yang mengacu pada kurikulum 2013 untuk melatih kemampuan berpikir kreatif siswa dengan menggunakan model saintifik yaitu mengamati, menanya, mengumpulkan informasi, mengasosisasikan dan mengkomunikasikan., Berdasarkan uraian di atas, peneliti merasa tertarik untuk melakukan penelitian dengan judul "Pengembangan Lembar Kerja Siswa (LKS) Model Saintifik Untuk Melatih Kemampuan Berpikir Kreatif Siswa Sekolah Dasar".

\section{METODE PENELITIAN}

Penelitian ini merupakan penelitian pengembangan (developmental research), dengan mengembangkan lembar kerja siswa model saintifik untuk melatih kemampuan berpikir kreatif siswa yang mengacu pada model 4-D (Four-D), model 4D (four D models) yang terdiri dari empat tahap, yaitu tahap pendefinisian (define), perancangan (design), pengembangan (develop) dan penyebaran (disseminate), Adapun teknik pengumpulan data pada penelitian ini yakni: observasi dan kuesioner (angket). Teknik analisis data penelitian diperoleh melalui analisis validasi perangkat pembelajaran, analisis kepraktisan perangkat pembelajaran, analisis keefektifan perangkat pembelajaran, meliputi: analisis respon siswa kemampuan berpikir kreatif.

\section{HASIL DAN PEMBAHASAN}

\section{A. Penyajian data Hasil Ujicoba}

Validasi lembar kerja siswa berdasarkan hasil pemeriksaan lembar kerja siswa oleh dua validator diperoleh bahwa pada lembar validasi lembar kerja siswa dapat dipahami oleh responden (siswa), validator pertaman memberikan keputusan dapat digunakan dengan revisi dan validator kedua memberikan keputusan dapat digunakan tanpa revisi. Validasi tes kemampuan berpikir kreatif yakni berdasarkan hasil penilaian oleh kedua validator terhadap tes kemampuan berpikir kreatif diperoleh bahwa tes kemampuan berpikir kreatif siswa yang telah dikembangkan dapat digunakan tanpa revisi. Validasi instrumen angket respon siswa hasil penilaian validitas angket respon siswa oleh kedua validator menyatakan valid dan dapat digunakan tanpa revisi dan angket respon siswa berdasarkan hasil penilaian pengisian angket respon siswa yang dilakukan oleh responden, secara umum dapat dikatakan bahwa siswa sangat tertarik terhadap materi pembelajaran dan lembar kerja siswa, dan tercipta suasana belajar yang baru serta sangat mudah memahami materi pembelajaran dan cara guru menjelaskan sangat jelas.

Validasi instrumen lembar pengamatan aktivitas siswa berdasarkan hasil penilaian oleh kedua validator terhadap instrumen validasi aktivitas siswa diputuskan bahwa lembar aktivitas siswa dapat digunakan tanpa revisi. Uji Responden (Siswa) dilakukan kepada lima siswa kelas III-a sekolah dasar untuk mengetahui kelayakan produk yang digunakan dan untuk mengukur sejauh mana tingkat kreatif siswa dengan menggunakan lembar kerja siswa. Penggunaan lembar kerja siswa dalam proses belajar akan dinilai dengan menggunakan lembar penilaian aktivitas siswa dan menggunakan lembar penilaian tes kemampuan berpikir kreatif.

\section{B. Analisis Data}

1) Analisis Validasi Perangkat Pembelajaran

Dari hasil penelitian dapat disimpulakan yakni validasi lembar kerja siswa, tes kemampuan berpikir kreatif, validasi instrumen angket respon siswa, validasi instrumen lembar pengamatan aktivitas siswa dapat dilihat dari grafik sebagai berikut: 


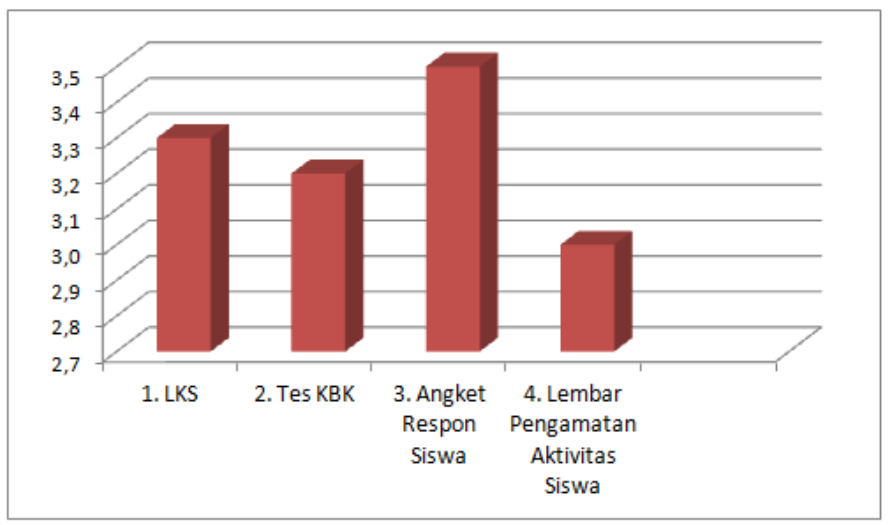

Gambar 1. Grafik Hasil Validasi Perangkat Pembelajaran

Berdasarkan diagram diatas dapat disimpulkan bahwa keempat point diatas yang telah divalidasi oleh kedua validator memberikan nilai pada kategori valid berdasarkan standar kriteria penilaian validasi perangkat pembelajaran.

2) Analisis Kepraktisan Pembelajaran

Analisis hasil lembar pengamatan aktivitas siswa adalah suatu analisis yang dilakukan setelah peneliti melakukan penelitian disajikan dalam bentuk statistik deskriptif untuk mengetahui kelayakan produk. Pada analisis pengamatan aktivitas siswa terhadap lima responden yang dilakukan pada pembelajaran satu dan dua materi pertumbuhan dan perkembangan tumbuhan terdapat sembilan aspek yang dinilai. Berdasarkan sembilan aspek tersebut, dapat diuraikan bahwa pengamatan aktivitas lima responden pada pembelajaran satu dan pembelajaran dua diperoleh realibilitas $98 \%$.

\section{3) Analisis Keefektifan Perangkat Pembelajaran}

Dalam analisis keefektifan perangkat pembelajaran terdapat dua point yang akan dibahas yakni analisis angket respon siswa dan analisis tes kemampuan berpikir kreatif hasil penelitian kedua poin tersebut akan dijabarkan dalam bentuk grafik sebagai berikut:

a. Analisis Angket Respon Siswa

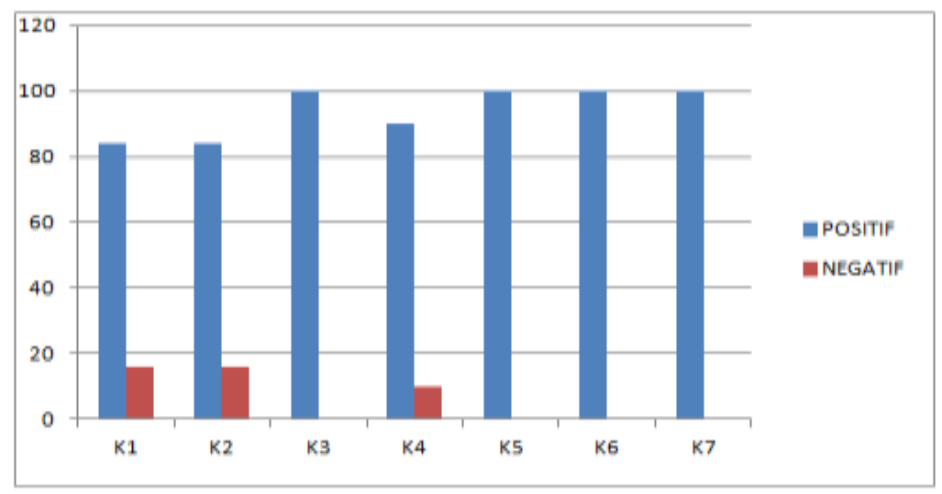

Gambar 2. Grafik Hasil Analisis Angket Respon Siswa

Analisis angket respon siswa dilakukan setelah dilaksanakannya kegiatan aktivitas siswa. Responden memberikan penilaian pada lembar angket respon siswa yang mencakup tujuh komponen dan masing-masing komponen memiliki dua sampai lima item. Pada komponen ini responden memberikan penilaian/pendapat dengan kriteria sangat tertarik atau tidak tertarik, sangat baru atau tidak baru, sangat mudah atau tidak mudah, sangat berminat atau tidak berminat, setuju atau tidak setuju, jelas atau tidak jelas dan mudah atau tidak mudah, Hasil penilaian angket respon siswa diperoleh enam komponen positif rentang nilai 81-100\% dengan kriteria sangat kuat dan satu komponen rentang nilai $61-80 \%$ dengan kriteria kuat, serta tiga 
komponen negatif rentang nilai 0-20\% dengan kriteria sangat lemah. Penilaian angket respon siswa dapat disimpulkan komponen positif dengan rerata 94\% dengan kriteria sangat kuat.

b. Analisis Tes Kemampuan Berpikir Kreatif

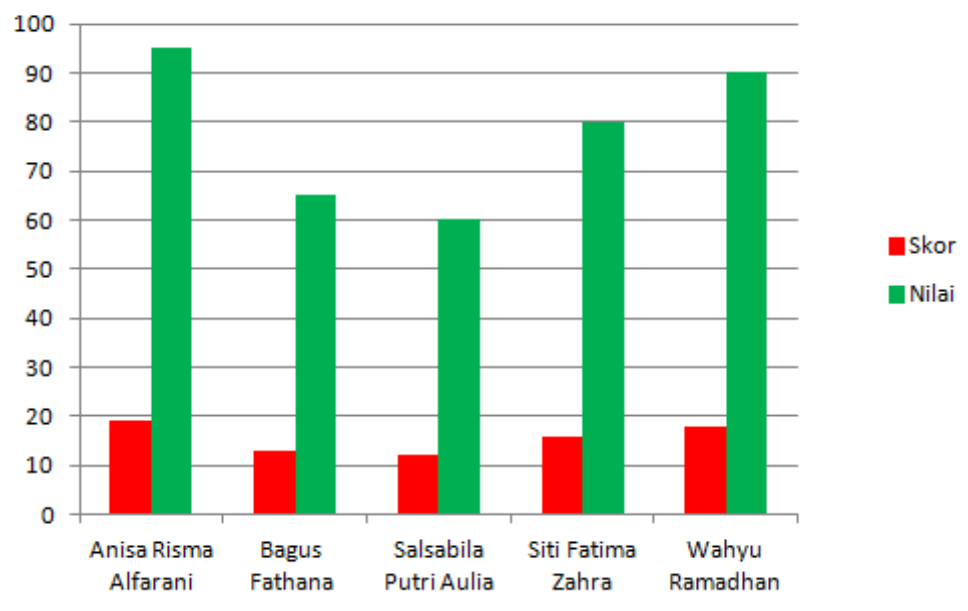

Gambar 3. Grafik Hasil Analisis Tes Kemampuan Berpikir Kreatif

Analisis tes kemampuan berpikir kreatif dilakukan setelah dilaksanakannya aktivitas siswa dalam mengerjakan soal kreatif. Pada komponen ini responden memberikan jawaban pada soal kreatif dengan kriteria penilaian sangat kreatif, kreatif, kurang kreatif dan tidak kreatif, Berdasarkan hasil penilaian tes kemampuan berpikir kreatif diperoleh data siswa yang pertama Anisa Risma Alfarani mendapatkan skor 19 dengan nilai 95 dapat dinyatakan sebagai kriteria sangat kreatif, kedua Bagus Fathana mendapatkan skor 13 dan nilai 65 dengan kriteria kreatif, ketiga Salsabila Putri Aulia dengan skor 12 dan nilai 60 mendapatkan kriteria kurang kreatif, keempat Siti Fatima Zahra dengan skor 16 dan nilai 80 kriteria kreatif dan kelima Wahyu Ramadhan mendapatkan skor 18 dan nilai 90 dengan kriteria sangat kreatif. Sehingga dalam penilaian tes kemampuan berpikir kreatif ini terdapat dua responden yang termasuk kategori sangat kreatif dan dua responden dengan kategori kreatif serta satu responden dinyatakan kurang kreatif.

\section{SIMPULAN DAN SARAN}

\section{A. Simpulan}

Berdasarkan hasil analisis validasi dan penyajian data pada pengembangan lembar kerja siswa model saintifik bahwa hasil analisis validasi perangkat pembelajaran yang terdiri dari lembar kerja siswa, tes kemampuan berpikir kreatif, pengamatan aktivitas siswa dan angket respon siswa oleh kedua validator secara umum mendapatkan jumlah rata-rata skor adalah 2,6 dengan rata-rata akhir 2,58 dan termasuk kategori "valid". Penilaian analisis lembar kerja siswa mendapatkan jumlah ratarata 3,3, tes kemampuan berpikir kreatif mendapatkan jumlah rata-rata 3,2. Pengamatan aktivitas siswa mendapatkan jumlah rata-rata 3,0 sedangkan untuk angket respon siswa diperoleh rata-rata 3,5. Dengan demikian hasil analisis validasi empat perangkat pembelajaran masuk kategori 'Layak' dan dapat digunakan dalam kegiatan pembelajaran.

Selanjutnya untuk mengetahui kepraktisan perangkat pembelajaran dilakukan analisis pengamatan aktivitas siswa. Berdasarkan pengamatan dan hasil analisis aktivitas siswa terhadap lima responden yang mencakup sembilan aspek penilaian pada pembelajaran satu dan dua diperoleh nilai rata-rata 124 dengan reliabilitas 98\%. Dengan demikian perangkat pembelajaran ini praktis untuk digunakan. Setelah perolehan data validitas dan kepraktisan, adapun hasil analisis keefektifan perangkat pembelajaran melalui angket respon siswa yang terdiri dari tujuh komponen pertanyaan. Berdasarkan hasil analisis angket respon siswa mendapatkan nilai rata-rata 92 dengan kriteria sangat kuat. Dan hasil tes kemampuan berpikir kreatif siswa terdapat dua siswa yang termasuk kategori sangat kreatif, dua siswa yang kategori kreatif serta satu siswa yang kategori kurang kreatif, Dengan demikian dapat ditarik kesimpulan bahwa pengembangan lembar kerja 
siswa model saintifik untuk melatih kemampuan berpikir kreatif siswa sekolah dasar layak digunakan

\section{B. Saran}

Berdasrkan hasil penelitian dan pembahasan, saran yang diperlukan pada penelitian ini diantaranya: (1) Diharapkan kepada guru agar dapat lebih memahami keragaman karakter siswa dan memberikan kegiatan pembelajaran yang bermakna dengan menerapkan model pembelajaran saintifik melalui aktivitas kegiatan dan lembar kerja siswa yang sudah memenuhi standar kriteria yang layak, (2) Bagi Sekolah, Diharapkan kepada sekolah agar terus memfasilitasi kegiatan pembelajaran siswa dan memberikan dukungan kepada guru untuk lebih semangat memanfaatkan teknologi yang berkembang saat ini khususnya dalam pembuatan lembar kerja siswa., (3) Peneliti berikutnya, penelitian yang lemah dikarenakan hanya dilakukan pada uji coba pertama. Jika ada yang menjadikan skripsi ini sebagai penelitian yang relevan diharapkan agar hasil pengembangan lembar kerja siswa model saintifik ini dapat dijadikan pembelajaran untuk ke depannya agar dapat menghasilkan lembar kerja siswa yang lebih kreatif dan dapat mencoba hal-hal baru dengan menggunakan model pembelajaran yang lain. Peneliti dapat mengembangkan terus ilmunya dan berbagi dengan orang lain.

\section{DAFTAR RUJUKAN}

Aditiya, Dinda. 2018. Pengaruh pendekatan Saintifik pada Pembelajaran Tematik Terhadap kemampuan Berpikir Kreatif Kelas IV SD Negeri 14 Padang Cermin Kabupaten Pesawaran. Skripsi. Bandar Lampung: Universitas Lampung.

Adrianto, T.T. 2013. Cara Cerdas Melejitkan IQ Kreatif Anak. Yogyakarta: Kata Hati.

Arfiyani, Agnis Livia Arum. 2018. Peningkatan Kemampuan Berpikir Kreatif dan Hasil Belajar Siswa Kelas V Pada Pembelajaran IPA Melalui metode Discovery Learning di SDN Ngamblak. Skripsi. Yogyakarta: Universitas Sanata Dharma.

Arini, Wahyu dkk. 2017. Analisis Kemampuan Berpikir Kreatif Pada Materi Cahaya Siswa Kelas III SMP XA Verius Kota Lubuklinggau. Science and Physics Education Journal (SPEJ) : 1(01).

Arsyad, Azhar. 2014. Media Pembelajaran. Jakarta: PT. Raja Gravindo Persada.

Awe, Elisabeth. 2016. Pengembangan Lembar Kerja Siswa Menggunakan Pendekatan Saintifik pada Subtema Bermain di Lingkungan Sekolah untuk Siswa Kelas Dua (II) Sekolah Dasar. Skripsi. Yogyakarta: Universitas Sanata Dharma.

Budiman, 2017. Pengembangan perangkat pembelajaran biologi model inkuiri terbimbing berkerakter budaya lokal "nggahi rawi pahu"untuk melatihkan kemampuan berpikir kritis siswa.Penelitian Dosen pemula. Dompu: STKIP Yapis Dompu.

Daryanto. 2014. Pendekatan Pembelajaran Saintifik Kurikulum 2013. Yogyakarta: Gaya Media.

Ghozali, Imam. 2017. Pendekatan Scientific Learning dalam meningkatkan Prestasi Belajar Siswa. Jurnal Pedagogik: 4(01): 4-5.

Kusumawati, Maria Advensia Sari. 2017. Pengembangan LKS IPA Berbasis Pendekatan Saintifik untuk Siswa kelas IV Materi Macam-macam Energi. Skripsi. Yogyakarta: Universitas Sanata Dharma.

Lismawati. 2010. Penyusunan Perangkat Pembelajaran. Yogyakarta: Insan Madani.

Mbasi, Edeltrudis. 2016. Pengembangan LKS menggunakan pendekatan saintifik pada subtema hewan di Sekitar untuk siswa kelas dua (II) Sekolah Dasar. Skripsi. Yogyakarta: Universitas Sanata Dharma.

Munandar, Utami. 2009. Pengembangan Kreativitas Anak Berbakat. Jakarta: Rineka Cipta. 
Permendikbud Nomor 57 Tahun 2014 Tentang Kurikulum 2013 sekolah Dasar. Jakarta: Depdiknas.

Permendikbud Nomor 65 Tahun 2013 Tentang Standar Proses Pendidikan Dasar dan Menengah. Jakarta: Depdiknas.

Putri, Aennur Falah. 2016. Pengembangan Lembar Kerja Siswa (LKS) Sebagai Bahan Ajar Pada Mata Pembelajaran Pengetahuan Bahan Makanan Bagi Siswa Kelas X Jasa Boga SMK Muhammadiyah 1 Moyudan. Skripsi: Universitas Negeri Yogyakarta.

Rawlinson, J Geoffrey. 1989. Berpikir Kreatif dan Sumbang Saran. Dalam I.D. Riskomar. Jakarta: Binapura Aksara.

Sani, Ridwan Abdullah. 2014. Pembelajaran Saintifik untuk Implementasi Kurikulum 2013. Jakarta: Bumi Aksara.

Sugiyono. 2018. Metode Penelitian Kuantitatif, Kualitatif dan R\&D. Bandung: Alfabeta.

Susanto, Ahmad. 2013. Teori Belajar dan Pembelajaran Di Sekolah Dasar. Jakarta: Kencana Prenada Media Group.

Tanti, Simon Pontok. 2018. Pengembangan Lembar kerja Siswa (LKS) dengan Media Gambar pada Mata Pembelajaran Akuntasi Untuk Siswa Kelas X SMK. Skripsi. Yogyakarta: Universitas Sanata Dharma.

Undang-Undang Republik Indonesia Nomor 20 Tahun 2003 Tentang Sistem Pendidikan Nasional. Jakarta: Depdiknas. 